\title{
Genetic Analysis of Bactrocera dorsalis (Diptera; Tephritidae) Populations Collected from Fruit Growing Areas in Western Tamil Nadu, India
}

\author{
V. Thangaraj ${ }^{1}$, S. Upasna ${ }^{1}$, T. Elaiyabharathi ${ }^{2}$, S. Rajesh $^{1}$ and S. Mohankumar $^{1 *}$ \\ ${ }^{1}$ Department of Plant Biotechnology, Centre for Plant Molecular Biology and Biotechnology, \\ Coimbatore-641003, Tamilnadu, India \\ ${ }^{2}$ Department of Agricultural Entomology, Centre for Plant for Plant Protection Studies, \\ Coimbatore-641003, Tamilnadu, India
}

*Corresponding author

\section{A B S T R A C T}

Keywords

Bactrocera

dorsalis, coxl,

$\operatorname{cox} 2$, Genetic

diversity, Western

Tamil Nadu

Article Info

Accepted:

04 June 2019

Available Online:

10 July 2019
Fruit flies under Tephritidae are one of the diverse and agriculturally important insects. It needs reliable taxonomic procedures to resolve species complexes and genetic structure analysis to effectively control this pest. Little attention has been given to the analysis of genetic diversity in South Indian populations. By using mitochondrial cytochrome oxidase I and II (coxl and cox2), the genetic analysis of B. dorsalis from eight locations of major fruit growing areas in western parts of Tamil Nadu were investigated. Genetic diversity indices such as a number of haplotypes $(\mathrm{H})$, haplotype diversity $(\mathrm{Hd})$, nucleotide diversity $(\pi)$, and the average number of nucleotide differences between sequences $(\mathrm{k})$ of the populations revealed that Bactrocera dorsalis has a high level of genetic diversity with distinct genetic structure. Future studies should concentrate on extensive sampling from varied geographical locations of south India along with complete species delimitation, and also microsatellite marker analysis which would enable us to understand the complete genetic and population structure of this pest. This information will be useful to devise an area-wide management programme for this destructive pest.

\section{Introduction}

Fruit flies under Tephritidae, are one of the most species-rich families in Diptera with distinguishing body colour and wing patterns (Aluja and Norrbom 1999, White and ElsonHarris 1992). But Dacini is one of the tribes in Tephritidae is having very few key observable features which lead to blurred species resolution for taxonomy and agricultural diagnostics. The tribe Dacini comprises totally 10 percentpest species on commercial fruits and vegetable crops (Vargas et al., 2015). For instance, the Bactrocera dorsalis complex has five sibling fruit fly species; $B$. dorsalis $B$. papayae (Drew and Hancock), B.philippinensis (Drew and Hancock), $B$. carambolae(Drew and Hancock), and $B$. invadens (Drew) due to overlapping morphological characters except for minor differences such as in colour patterns (Drew and Hancock 1994), genital characters (Iwahashi 2001) including length of aedeagus (Drew et al., 2008), and variations in wing 
shape (Schutze et al., 2012). But now, all the sibling fruit flies were synonymized as $B$. dorsalis (San Jose et al., 2018). In addition, generic complex assignment of the Dacini tribe by molecular data resulted in four genera, including important pestiferous genera such as Bactrocera, Zeugodacus, Dacus. However, few scientists (Drew and Hancock, 2016) considered Zeugodacus as subgenus of the genus Bactrocera. Due to inconclusiveness in morphological and molecular studies, there is incongruence between both aspects which necessitates a reliable taxonomic starting point. As ecological studies that focus on the behavior of species, host selection, distributional patterns or pollination associations are hindered when species are inaccurately identified (San Jose et al., 2018).

In India, fruit flies have been recognized among the ten most serious pests of agricultural crops causing annual monetary losses to the tune of rupees 7000 corers. Furthermore, as the larvae feed and develop from inside the fruit, there is an increasing threat of migration of fruit flies through the export of fruits and vegetables.

For instance, among the Dacini flies, $B$. dorsalis poses the most important quarantine pest status, because of its extreme invasiveness and high survivability to the newer ecological niches. Hence, the global horticultural industry including India is facing significant threat due to the detrimental effect of this pest. To address the impact of important invasive fruit flies, the International Plant Protection Convention (IPPC) has created diverse International Standards for Phytosanitary Measures (ISPM). The standards cover all aspects related to invasive risk assessments, monitoring, management, and control (Jiang et al., 2018).

Therefore to devise an effective pest management strategies, for instance, Area-
Wide Integrated Pest Management (AWIPM), Sterile Insect Technique (SIT) programme and timely application of quarantine treatments will rely upon the key issues such as genetic diversity, genetic and population structure and gene flow of the concerned species (Qin et al., 2016, Choudhary et al., 2016, Jiang et al., 2018).

An informative and neutral molecular marker can be obtained from invertebrate Mitochondrial DNA (mtDNA) which may be useful in phylogeographic structure analysis (Wan et al., 2011)and for determining intra and inter-specific relationships.

Since, it has features such as high copy numbers, haploid mode of inheritance with no recombination, lack of introns makes molecular evolution as constant with moderate rate, and a lower effective population size (Mun et al., 2003; Nardi et al., 2005; Prabhakar et al., 2013; Prabhakar et al., 2012; Wan et al., 2012; Simon et al., 1994; Roderick 1996). Hence, we analyzed two mitochondrial genes ( $\operatorname{cox} 1$ and $\operatorname{cox} 2$ ) of adult fruit flies species of $B$. dorsalis, collected from the Western agroclimatic zone of Tamil Nadu to infer about the genetic diversity of this mango fruitfly.

\section{Materials and Methods}

\section{Field sampling}

B. dorsalis adults were collected from various fruit growing regions in the Western agroclimatic zone of Tamil Nadu (i.e. Krishnagiri, Dharmapuri, Coimbatore districts) from 2017 to 2018. The collection sites encompass locations that varied in latitude and longitude as furnished in (Table 1). Fruit flies were trapped using methyl eugenol traps and preserved in 70 percent ethanol and further stored at $-20^{\circ} \mathrm{C}$ until DNA extraction. 
DNA extraction, amplification, and genotyping

Genomic DNA was isolated from the legs of a single insect of $B$. dorsalis from each geographical locations by using the HotSHOT method (Montero- Pau et al., 2008). Two buffers were utilized viz., alkaline lysis buffer (pH 12) which contained $25 \mathrm{mM} \mathrm{NaOH}$, $0.2 \mathrm{mM} \mathrm{Na} \mathrm{N}_{2} \mathrm{EDTA}$, and neutralizing solution contained 40mM Tris-HCl. Six legs of individual fruit fly sample were removed and homogenized with $100 \mu \mathrm{l}$ alkaline lysis buffer $(\mathrm{pH} 12)$ with micropestle and incubated at $95^{\circ} \mathrm{C}$ in a hot water bath for 30 minutes.

After incubation, the samples were removed from the hot water bath and were allowed to cool at $4^{\circ} \mathrm{C}$ in a refrigerator for $5-10$ mins. Then, $100 \mu 1$ of the neutralizing solution was added to each tube, vortexed and spun to settle down the debris. The extracted DNA samples were stored at $-20^{\circ} \mathrm{C}$.

The two fragments of mitochondrial gene (Cytochrome oxidase I and II) were amplified using the primer pairs coxl, LCO 1490 (GGTCAACAAATCATAAAGATATTGG) $\mathrm{HCO}$ 2198 (TAAACTTCAGGGTGACCAAAAAATCA) (Vrijenhoek 1994) and Tephriditae specific cox2 of the mitochondrial gene (Cytochrome oxidase II) using the primer pairsTephFdeg (GACAACATGAGCHGSHYTHGGBCT) and (GCTCCACAAATTTCTGAACATTG)

(Jiang et al., 2018). Polymerase chain reactions (PCR) were carried out in $25 \mu 1$ of cocktail mixtures containing, $11.5 \mu \mathrm{l}$ of nuclease-free water, $2.5 \mu 1$ of reaction buffer (10X with $25 \mathrm{Mm} \mathrm{MgCl}_{2}$ ), $2.5 \mu$ ldNTPs, $1.5 \mu 1$ of forward primer, $1.5 \mu \mathrm{l}$ of reverse primer, $1 \mu 1$ of $25 \mathrm{Mm} \mathrm{MgCl} 2$ and $1 \mu 1$ of DMSO (Dimethyl sulfoxide) (as PCR additives)and 5 of $\mu 1$ of template DNA. The PCR amplification of coxl was accomplished by initial denaturation for $2 \mathrm{~min}$ at $94^{\circ} \mathrm{C}, 35$ cycles of denaturation at $94^{\circ} \mathrm{C}$ for $1 \mathrm{~min}$, primer annealing for $1 \mathrm{~min}$ at $52^{\circ} \mathrm{C}$ and an extension for $1 \mathrm{~min}$ at $72^{\circ} \mathrm{C}$ and final extension step at $72^{\circ} \mathrm{C}$ for $5 \mathrm{~min}$ and the storage and cooling temperature was held at $4^{\circ} \mathrm{C}$.

The PCR amplification of cox2 was accomplished by initial denaturation for $3 \mathrm{~min}$ at $94^{\circ} \mathrm{C}, 35$ cycles of denaturation at $94^{\circ} \mathrm{C}$ for $15 \mathrm{sec}$, primer annealing for $1 \mathrm{~min}$ at $52^{\circ} \mathrm{C}$ and an extension for $1 \mathrm{~min}$ at $60^{\circ} \mathrm{C}$ and final extension step at $60^{\circ} \mathrm{C}$ for $5 \mathrm{~min}$ and the storage and cooling temperature was held at $4^{\circ} \mathrm{C}$. Amplified products of coxl and cox 2 genes were separated using agarose gel electrophoresis $[1.5 \%(w / v)]$. Amplified PCR products $(20 \mu \mathrm{l})$ were sequenced at Agrigenome labs Pvt. Ltd., Cochin, Kerala.

\section{Sequence analysis}

Mitochondrial DNA gene coxl and cox2partial sequences were aligned by using Geneious v.11.1.3 software. After manual correction and assembly, unique sequences were deposited in gene bank under accession numbers MN016984 to MN016996 for coxl, and MN017012 to MN017024 for cox2 gene sequences. Pairwise differences between sequences $(\mathrm{k})$ were calculated in MEGA v6.06 (Tamura et al., 2013).

Descriptive statistics number of haplotypes (H), Haplotype diversity, nucleotide diversity $(\pi)$, and the average number of nucleotide differences between sequences $(\mathrm{k})$ were calculated in DnaSP v5.0 software (Librado and Rozas 2009). Evidence of genetic structuring was assessed by analysis of molecular variance (AMOVA) and population comparisons and differentiation using the Tamura and $\mathrm{Nei}+\gamma$ model in ARLEQUIN version 3.5.2.2 (Excoffier and Lischer, 2010) with the resulting phi statistics assessed using 10,000 permutations at 0.05 significance level. 


\section{Results and Discussion}

In the current study, we used the sequences of B.dorsalis obtained from eight locations (accession number of coxl: MN016984 to MN016996; cox2: MN017012 to MN017024) of Western Agroclimatic zone of Tamil Nadu. The aligned mtDNA coxland cox2 genes partial sequences used for genetic diversity analysis of B.dorsalis in different fruit growing areas of Krishnagiri, Dharmapuri, Coimbatore districts. A final sequences length of 634 and $598 \mathrm{bp}$ for coxl and cox 2 genes respectively, were used for analysis. Overall 81 variable sites, including 51 parsimony informative sites and 30 singleton sites in the coxl gene and 52 variable sites including 15 parsimony informative sites and 37 singleton sites in cox 2 gene were observed in the nucleotide sequence alignment.

Analysis of sequences revealed that 12 haplotypesin the coxl gene and 14 haplotypes in the cox2 gene were detected from all the populations of $B$. dorsalis (Table 2). Among
12 haplotypes detected in the coxl gene, only four were shared by at least two populations and remaining 12 haplotypes were exclusive haplotypes unshared by any other populations. Likewise, only two out of 14 haplotypes detected in the cox2 gene, were shared haplotypes. Results obtained from descriptive genetic diversity analysis such as Haplotype diversity, the average number of nucleotide differences (k), nucleotide diversity (p) of eight populations based on both gene sequences are summarized in (Table 3 and 4). Results of genetic diversity indices indicated that almost all the populations retain higher levels of genetic diversity. The analysis of molecular variance (AMOVA) showed that most of the genetic variation was present among the populations (51.62 from coxl and $66.11 \%$ from $\operatorname{cox} 2$ gene sequences, $\mathrm{P}<0.001)$ than within the populations $(48.38 \%$ from coxl and $33.89 \%$ from cox 2 gene sequences, $\mathrm{P}<0.001)$ (Table 5). The overall fixation index (Fst) calculated for all populations with both genes were statistically significant $(0.51$ at $\mathrm{P}<0.01$ and 0.66 at $\mathrm{P}<0.01$ levels)

Table.1 Locations of B. dorsalis sample collected from the western agroclimatic zone of Tamil Nadu

\begin{tabular}{|l|l|l|l|l|l|}
\hline S. No & Code & District & Locations & Latitude & Longitude \\
\hline 1. & Cbe & Coimbatore & Coimbatore & $11.0120^{\circ} \mathrm{N}$, & $76.9378^{\circ} \mathrm{E}$ \\
\hline 2. & Dpi-Km & Dharmapuri & Karimangalam & $12.3060^{\circ} \mathrm{N}$, & $78.2045^{\circ} \mathrm{E}$ \\
\hline 3. & Dpi-Mo & & Morapur & $12.1281^{\circ} \mathrm{N}$, & $78.3913^{\circ} \mathrm{E}$ \\
\hline 4. & Dpi-Pe & & Pennagaram & $12.1334^{\circ} \mathrm{N}$, & $77.8967^{\circ} \mathrm{E}$ \\
\hline 5. & Kki-Ho & \multirow{2}{*}{ Krishnagiri } & Hosur & $12.7409^{\circ} \mathrm{N}$, & $77.8253^{\circ} \mathrm{E}$ \\
\hline 6. & Kki-Kp & & Kaveripattinam & $12.4215^{\circ} \mathrm{N}$, & $78.2174^{\circ} \mathrm{E}$ \\
\hline 7. & Kki-Ve & & Veppanapalli & $12.7020^{\circ} \mathrm{N}$, & $78.1942^{\circ} \mathrm{E}$ \\
\hline 8. & Kki-Py & & Paiyur & $12.3696^{\circ} \mathrm{N}$, & $78.2191^{\circ} \mathrm{E}$ \\
\hline
\end{tabular}

Table.2 Descriptive statistics of Genetic diversity of $B$. dorsalis populations based oncoxl and cox2 partial sequences

\begin{tabular}{|l|l|l|l|l|l|l|}
\hline Species & Marker & $\begin{array}{l}\text { Number of } \\
\text { polymorphic } \\
\text { sites }\end{array}$ & $\begin{array}{l}\text { Haplotype } \\
(\mathbf{H})\end{array}$ & $\begin{array}{l}\text { Haplotype } \\
\text { diversity } \\
(\mathbf{H d} \pm \text { SD) }\end{array}$ & $\begin{array}{l}\text { Average number } \\
\text { of nucleotide } \\
\text { differences } \\
\text { (K } \pm \text { SD) }\end{array}$ & $\begin{array}{l}\text { Nucleotide } \\
\text { diversity }(\boldsymbol{\pi} \pm \text { SD) }\end{array}$ \\
\hline \multirow{2}{*}{ B. dorsalis } & $\operatorname{cox} 1$ & 62 & 12 & $0.917 \pm 0.031$ & $9.133 \pm 1.452$ & $0.0145 \pm 0.00663$ \\
\cline { 2 - 7 } & $\operatorname{cox} 2$ & 51 & 14 & $0.983 \pm 0.028$ & $12.108 \pm 2.049$ & $0.0204 \pm 0.00643$ \\
\hline
\end{tabular}


Table.3 Descriptive statistics of Genetic diversity of B. dorsalis populations based on coxI sequences

\begin{tabular}{|l|l|l|l|l|l|l|l|}
\hline $\begin{array}{l}\text { S. } \\
\text { No }\end{array}$ & Code & Location & $\begin{array}{l}\text { Polymorphic } \\
\text { site }\end{array}$ & $\begin{array}{l}\text { Haplotype } \\
\mathbf{( H )}\end{array}$ & $\begin{array}{l}\text { Haplotype } \\
\text { diversity } \\
(\mathbf{H d} \pm \mathbf{S D})\end{array}$ & $\begin{array}{l}\text { Average number } \\
\text { of } \\
\text { differences } \\
\text { nucleotide }\end{array}$ & $\begin{array}{l}\text { Nucleotide } \\
\text { diversity } \\
(\boldsymbol{\pi} \pm \mathbf{S D})\end{array}$ \\
\hline $\mathbf{1 .}$ & Cbe & Coimbatore & 0 & 1 & 0 & 0 & 0 \\
\hline $\mathbf{2 .}$ & Ho & Hosur & 4 & 2 & $1.000 \pm 0.500$ & $4.000 \pm 2.707$ & $0.0057 \pm 0.0028$ \\
\hline $\mathbf{3 .}$ & Mo & Morapur & 7 & 2 & $1.000 \pm 0.500$ & $7.000 \pm 4.583$ & $0.0105 \pm 0.0052$ \\
\hline $\mathbf{4 .}$ & $\mathrm{Km}$ & Karimangalam & 4 & 2 & $1.000 \pm 0.500$ & $4.000 \pm 2.707$ & $0.0060 \pm 0.0030$ \\
\hline $\mathbf{5 .}$ & $\mathrm{Kp}$ & Kaveripattinam & 4 & 2 & $1.000 \pm 0.500$ & $4.000 \pm 2.707$ & $0.0060 \pm 0.0040$ \\
\hline $\mathbf{6 .}$ & $\mathrm{Py}$ & Paiyur & 4 & 2 & $1.000 \pm 0.500$ & $4.000 \pm 2.707$ & $0.0058 \pm 0.0028$ \\
\hline $\mathbf{7 .}$ & $\mathrm{Pe}$ & Pennagaram & 2 & 2 & $1.000 \pm 0.500$ & $2.000 \pm 1.452$ & $0.0031 \pm 0.0015$ \\
\hline $\mathbf{8 .}$ & $\mathrm{Ve}$ & Veppanapalli & 7 & 2 & $1.000 \pm 0.500$ & $7.000 \pm 4.583$ & $0.0100 \pm 0.0049$ \\
\hline
\end{tabular}

Table.4 Descriptive statistics of Genetic diversity of $B$. dorsalis populations based on cox2 sequences

\begin{tabular}{|c|c|c|c|c|c|c|c|}
\hline $\begin{array}{l}\text { S. } \\
\text { No }\end{array}$ & Code & Location & $\begin{array}{l}\text { Polymorphic } \\
\text { site }\end{array}$ & $\begin{array}{l}\text { Haplotype } \\
\text { (H) }\end{array}$ & $\begin{array}{l}\text { Haplotype } \\
\text { diversity } \\
(\text { Hd } \pm \text { SD) }\end{array}$ & $\begin{array}{l}\text { Average } \\
\text { number of } \\
\text { nucleotide } \\
\text { differences } \\
(\mathrm{K} \pm \text { SD) }\end{array}$ & $\begin{array}{l}\text { Nucleotide } \\
\text { diversity }(\pi \pm \text { SD) }\end{array}$ \\
\hline 1. & Cbe & Coimbatore & 2 & 2 & $1.000 \pm 0.500$ & $2.000 \pm 1.450$ & $0.0033 \pm 0.0016$ \\
\hline 2. & Ho & Hosur & 5 & 2 & $1.000 \pm 0.500$ & $5.000 \pm 3.333$ & $0.0083 \pm 0.0041$ \\
\hline 3. & Mo & Morapur & 6 & 2 & $1.000 \pm 0.500$ & $6.000 \pm 3.959$ & $0.0099 \pm 0.0050$ \\
\hline 4. & $\mathrm{Km}$ & Karimangalam & 5 & 2 & $1.000 \pm 0.500$ & $5.000 \pm 3.333$ & $0.0083 \pm 0.0041$ \\
\hline 5. & $\mathrm{Kp}$ & Kaveripattinam & 4 & 2 & $1.000 \pm 0.500$ & $4.000 \pm 2.707$ & $0.0067 \pm 0.0033$ \\
\hline 6. & Py & Paiyur & 6 & 2 & $1.000 \pm 0.500$ & $6.000 \pm 3.959$ & $0.0099 \pm 0.0049$ \\
\hline 7. & $\mathrm{Pe}$ & Pennagaram & 2 & 2 & $1.000 \pm 0.500$ & $2.000 \pm 1.453$ & $0.0033 \pm 0.0016$ \\
\hline 8. & $\mathrm{Ve}$ & Veppanapalli & 8 & 2 & $1.000 \pm 0.500$ & $8.000 \pm 5.205$ & $0.0132 \pm 0.0066$ \\
\hline
\end{tabular}

Table.5 Summary of AMOVA analysis of different populations of B. dorsalis

\begin{tabular}{|c|c|c|c|c|c|c|}
\hline $\begin{array}{l}\text { Gene } \\
\text { analyzed }\end{array}$ & $\begin{array}{l}\text { Source of } \\
\text { variation }\end{array}$ & df & $\begin{array}{l}\text { Sum of } \\
\text { squares }\end{array}$ & $\begin{array}{l}\text { Variance } \\
\text { components }\end{array}$ & $\begin{array}{l}\text { Percentage of } \\
\text { variation }\end{array}$ & $\begin{array}{l}\text { Fixation } \\
\text { index }\end{array}$ \\
\hline \multirow[t]{3}{*}{$\operatorname{Cox} 1$} & $\begin{array}{l}\text { Among } \\
\text { populations }\end{array}$ & 7 & 112.44 & $5.469 \mathrm{Va}$ & 51.62 & \multirow[t]{3}{*}{$\mathrm{F}_{s t} 0.51 *$} \\
\hline & $\begin{array}{l}\text { Within } \\
\text { populations }\end{array}$ & 8 & 41.000 & $5.125 \mathrm{Vb}$ & 48.38 & \\
\hline & Total & 15 & 153.44 & 10.594 & & \\
\hline \multirow[t]{3}{*}{$\operatorname{Cox} 2$} & $\begin{array}{l}\text { Among } \\
\text { populations }\end{array}$ & 7 & 75.062 & $4.268 \mathrm{Va}$ & 66.11 & \multirow[t]{3}{*}{$\mathrm{F}_{s t} 0.66^{*}$} \\
\hline & $\begin{array}{l}\text { Within } \\
\text { populations }\end{array}$ & 8 & 17.500 & $2.188 \mathrm{Vb}$ & 33.89 & \\
\hline & Total & 15 & 92.562 & & & \\
\hline
\end{tabular}

* significant at $\mathrm{P}<0.01$ level. 
Analysis of partial mtDNA sequences proved the significant level of genetic diversity was found to exist within and among populations, as exemplified by high values of haplotype diversity, the average number of nucleotide differences, and nucleotide diversity from both coxl and cox2 genes. Haplotype diversity $(\mathrm{Hd}>0.5)$ and nucleotide diversity $(\pi>0.005) \quad$ except for Coimbatore and Pennagaram locations were high.

The observed high value of genetic diversity indicated that the analyzed populations were stable with a very long evolutionary history. The possible justification for Coimbatore $(\pi=0.0<0.005$ for coxland $\pi=0.0033<0.005$ for $\operatorname{cox} 2)$ and Pennagaram $(\pi=0.030<0.005$ for coxland $\pi=0.0031<0.005$ for cox 2 ) populations showed that the moderate genetic diversity might be due to collection of samples from a smaller portion of populations. Krishnagiri and Dharmapuri districts being the main horticultural hub of Tamil Nadu which might have paved way for the pest to reside continuously throughout the year in fruit fly orchards. Hence, the number of generations per year are being constant may be the reason behind the high level of genetic diversity. These results are in accordance with (Aketarawong et al., 2007) who predicted that the origin of Indian populations.

The molecular variance results obtained from both cox 1 and cox 2 genes demonstrated that the same as above that the observed genetic differentiation was higher because of significant high fixation index $\left(\mathrm{F}_{s t}\right)$ value for both coxl, $\left(\mathrm{F}_{s t} 0.51>0.25 @ \mathrm{P}<0.01\right)$ and cox2, $\left(\mathrm{F}_{s t} 0.66>0.25 @ \mathrm{P}<0.01\right)$ (Table 5). It was evident that the existence of population differentiation among populations because overall genetic differentiation between the populations having highly significant values (51.62, 66.11 as percent variance for coxl, cox2, respectively), as compared to differentiation within the populations (48.38, 33.89 as percent variance for $\operatorname{cox} 1, \operatorname{cox} 2$, respectively). The results are in contrast to the other Indian populations (Choudhary et al., 2016).Although Coimbatore location had a small proportion of populations having significant pairwise differences (varied from 0.929 to 1.000 for coxland 0.892 to 930 for cox2) (Table 5) indicating little gene flow between Coimbatore and all other populations in Krishnagiri and Dharmapuri districts. The high genetic differentiation with limited gene flow is likely to be attributed to the presence of cryptic species within each location. Because of having high value in the average pairwise difference across sequence for both coxl $(9.133 \pm 1.452 \quad$ bp), and $\operatorname{cox} 2$ $(12.108 \pm 2.049 \mathrm{bp})$ and with the range pairwise difference between sequences being $0 \%-7.2 \%$ (Table 5).

Hence, the species delimitation process is very important which can be solved by using an alternate identification system such as PCR-RFLP analyses for this B. dorsalis complex(Chua et al., 2010). Moreover, the existing genetic pattern may be explained by wolbachia infection mediated hybrid inviability between populations. As wolbachia is one of the speciation agents, that increases speciation rates between sibling species of the tephritid fruit flies (Jamnongluk et al., 2003).

Therefore determination of infection status of wolbachia in various populations can be explored for this destructive pest. Also, the current pattern of gene flow can be confirmed by fast-evolving microsatellite marker analysis with extensive sampling from varied biogeographical locations of south India. Concurrently, B. dorsalis mtDNA genes (cox 1 and cox2) partial sequences (26 in total)can serve as a representative sequence for the Tamil Nadu locations which will enrich the database of this pest. 


\section{Acknowledgment}

V.T was provided post-graduate fellowship by Department of Biotechnology, Ministry of Science and Technology, Govt of India, New Delhi.We thank TANII project members for providing samples collected from different sampling locations.

\section{References}

Aketarawong, N, M Bonizzoni, S Thanaphum, LM Gomulski, G Gasperi, AR Malacrida, and CR Gugliemino. 2007. "Inferences on the population structure and colonization process of the invasive oriental fruit fly, Bactrocera dorsalis (Hendel)." Molecular Ecology 16(17): 3522-3532.

Aluja, Martin, and Allen Norrbom. 1999. Fruit flies (Tephritidae): phylogeny and evolution of behavior: Crc Press.

Choudhary, Jaipal S, Naiyar Naaz, Chandra S Prabhakar, and Moanaro Lemtur. 2016. "Genetic analysis of oriental fruit fly, Bactrocera dorsalis (Diptera: Tephritidae) populations based on mitochondrial coxl and nadl gene sequences from India and other Asian countries." Genetica 144 (5): 611-623.

Chua, Tock H, Yi Vern Chong, and Saw Hoon Lim. 2010. "Species determination of Malaysian Bactrocera pests using PCR-RFLP analyses (Diptera: $\quad$ Tephritidae)." Pest management science 66(4): 379-384.

Drew, RAI, and DL Hancock. 2016. "A review of the subgenus' Bulladacus' drew and hancock of'bactrocera'Macquart (Diptera: Tephritidae: Dacinae), with description of two new species from Papua New Guinea." Australian Entomologist, The 43 (4):189.

Drew, Richard AI, and David Lawrence Hancock. 1994. "The Bactrocera dorsalis complex of fruit flies (Diptera: Tephritidae: Dacinae) in Asia." Bulletin of Entomological Research Supplement Series, 2: 1-68.

Drew, Richard AI, S Raghu, and Peter Halcoop. 2008. "Bridging the morphological and biological species concepts: studies on the Bactrocera dorsalis (Hendel) complex (Diptera: Tephritidae: Dacinae) in South-east Asia." Biological Journal of the Linnean Society, 93(2): 217-226.

Excoffier, Laurent, and Heidi EL Lischer. 2010. "Arlequin suite ver 3.5: a new series of programs to perform population genetics analyses under Linux and Windows." Molecular ecology resources 10 (3): 564-567.

Iwahashi, Osamu. 2001. "Aedeagal length of the Oriental fruit fly, Bactrocera dorsalis (Hendel) (Diptera: Tephritidae), and its sympatric species in Thailand and the evolution of a longer and shorter aedeagus in the parapatric species of B. dorsalis." Applied Entomology and Zoology, 36(3): 289-297.

Jamnongluk, Wanwisa, Visut Baimai, and Pattamaporn Kittayapong. 2003. "Molecular evolution of tephritid fruit flies in the genus Bactrocera based on the cytochrome oxidase I gene." Genetica 119(1): 19-25.

Jiang, Fan, Liang Liang, Zhihong Li, Yanxue $\mathrm{Yu}$, Jun Wang, Yuping $\mathrm{Wu}$, and Shuifang Zhu. 2018. "A conserved motif within cox 2 allows broad detection of economically important fruit flies (Diptera: Tephritidae)." Scientific reports 8(1): 2077.

Librado, Pablo, and Julio Rozas. 2009. "DnaSP v5: a software for comprehensive analysis of DNA polymorphism data." Bioinformatics 25(11): 1451-1452. 
MonteroPau, Javier, Africa Gómez, and Joaquín Muñoz. 2008. "Application of an inexpensive and highthroughput genomic DNA extraction method for the molecular ecology of zooplanktonic diapausing eggs." Limnology and Oceanography: Methods 6(6): 218-222.

Mun, Jeomhee, Andrew J Bohonak, and George K Roderick. 2003. "Population structure of the pumpkin fruit fly Bactrocera depressa (Tephritidae) in Korea and Japan: Pliocene allopatry or recent invasion?" Molecular Ecology 12(11): 2941-2951.

Nardi, Francesco, Antonio Carapelli, Romano Dallai, George K Roderick, and Francesco Frati. 2005. "Population structure and colonization history of the olive fly, Bactrocera oleae (Diptera, Tephritidae)." Molecular Ecology 14(9): 2729-2738.

Prabhakar, Chandra S, Pawan K Mehta, Pankaj Sood, Sunil K Singh, Prachi Sharma, and Prem N Sharma. 2012. "Population genetic structure of the melon fly, Bactrocera cucurbitae (Coquillett) (Diptera: Tephritidae) based on mitochondrial cytochrome oxidase (COI) gene sequences." Genetica 140(1-3): 83-91.

Prabhakar, Chandra S, Pankaj Sood, Pawan K Mehta, and Prem N Sharma. 2013. "Population genetic structure of the pumpkin fruit fly, Bactrocera tau (Walker) (Diptera: Tephritidae) in Himachal Pradesh, India." Biochemical systematics and ecology 51: 291-296.

Qin, Yu-Jia, Nopparat Buahom, Matthew N Krosch, $\mathrm{Yu} \mathrm{Du}, \mathrm{Yi} \mathrm{Wu}$, Anna $\mathrm{R}$ Malacrida, Yu-Liang Deng, Jia-Qi Liu, Xiao-Long Jiang, and Zhi-Hong Li. 2016. "Genetic diversity and population structure in Bactrocera correcta (Diptera: Tephritidae) inferred from mtDNA cox1 and microsatellite markers." Scientific Reports 6: 38476.
Roderick, George K. 1996. "Geographic structure of insect populations: gene flow, phylogeography, and their uses." Annual review of entomology 41(1): 325-352.

San Jose, Michael, Camiel Doorenweerd, Luc Leblanc, Norman Barr, Scott Geib, and Daniel Rubinoff. 2018. "Incongruence between molecules and morphology: A seven-gene phylogeny of Dacini fruit flies paves the way for reclassification (Diptera: Tephritidae)." Mol Phylogenet Evol 121:139-149.

Schutze, Mark K, Matthew N Krosch, Karen F Armstrong, Toni A Chapman, Anna Englezou, Anastasija Chomič, Stephen L Cameron, Deborah Hailstones, and Anthony R Clarke. 2012. "Population structure of Bactrocera dorsalis ss, B. papayae and B. philippinensis (Diptera: Tephritidae) in southeast Asia: evidence for a single species hypothesis using mitochondrial DNA and wing-shape data." BMC Evolutionary Biology 12 (1): 130 .

Simon, Chris, Francesco Frati, Andrew Beckenbach, Bernie Crespi, Hong Liu, and Paul Flook. 1994. "Evolution, weighting, and phylogenetic utility of mitochondrial gene sequences and a compilation of conserved polymerase chain reaction primers." Annals of the entomological Society of America 87(6): 651-701.

Tamura, Koichiro, Glen Stecher, Daniel Peterson, Alan Filipski, and Sudhir Kumar. 2013. "MEGA6: molecular evolutionary genetics analysis version 6.0." Molecular biology and evolution 30(12): 2725-2729.

Vargas, Roger, Jaime Piñero, and Luc Leblanc. 2015. "An overview of pest species of Bactrocera fruit flies (Diptera: Tephritidae) and the integration of biopesticides with other biological approaches for their 
management with a focus on the Pacific Region." Insects 6 (2): 297-318.

Vrijenhoek, R. 1994. "DNA primers for amplification of mitochondrial cytochrome c oxidase subunit I from diverse metazoan invertebrates." $\mathrm{Mol}$ Mar Biol Biotechnol 3 (5): 294-299.

Wan, Xuanwu, Yinghong Liu, and Bin Zhang. 2012. "Invasion history of the oriental fruit fly, Bactrocera dorsalis, in the Pacific-Asia region: two main invasion routes." PLoS One 7 (5):e36176.

Wan, Xuanwu, Francesco Nardi, Bin Zhang, and Yinghong Liu. 2011. "The oriental fruit fly, Bactrocera dorsalis, in China: origin and gradual inland range expansion associated with population growth." PLoS One 6 (10): e25238.

White, Ian M, and Marlene M Elson-Harris. 1992. Fruit flies of economic significance: their identification and bionomics: CAB International.

Zolfagharian, Hossein, Mohammad Mohajeri, and Mahdi Babaie. 2015. "Honey bee venom (Apis mellifera) contains anticoagulation factors and increases the blood-clotting time." Journal of Pharmacopuncture 18(4): 7.

\section{How to cite this article:}

Thangaraj, V., S. Upasna, T. Elaiyabharathi, S. Rajesh and Mohankumar, S. 2019. Genetic Analysis of Bactrocera dorsalis (Diptera; Tephritidae) Populations Collected from Fruit Growing Areas in Western Tamil Nadu, India. Int.J.Curr.Microbiol.App.Sci. 8(07): 58-66. doi: https://doi.org/10.20546/ijcmas.2019.807.008 